\title{
Attention deficit/hyperactivity disorder (ADHD): Complex phenotype, simple genotype?
}

Maria Teresa Acosta, ${ }^{\star} \mathrm{MD}^{1,2}$, Mauricio Arcos-Burgos, ${ }^{\star} \mathrm{MD}, \mathrm{PhD}^{2}$, and Maximilian Muenke, $\mathrm{MD}^{2}$

\begin{abstract}
Complex genetic traits refer to those phenotypes not fitting patterns of Mendelian segregation and/or assortment but exhibiting a preferential familial clustering that cannot be explained by cultural or environmental causes. Attention-deficit/hyperactivity disorder (ADHD) is the most common neurodevelopmental disorder of childhood and probably the most controversial. ADHD has been considered a complex genetic trait based upon the absence of a clear-cut boundary between affected and unaffected status. Furthermore, its high comorbidity with other disorders strongly suggests complex epistatic or pleiotropic effects acting in common with the environmental influences. This implies that the same gene or genes is or are associated with different and concurrently occurring phenotypes. In this study, we will review clinical and epidemiological aspects related to the ADHD phenotype, which are considered either as categorical or continuous traits. We also will discuss genetic models underlying the complexity of this behavioral phenotype and the probable role of epistatic interactions between major genes contributing to the ADHD phenotype. Genet Med 2004:6(1):1-15.
\end{abstract}

Key Words: Attention-deficit/hyperactivity disorder, autism, schizophrenia, epistasis, pleiotropy

Complex genetic traits exhibit a preferential familial clustering that cannot be explained by cultural or environmental causes alone,,$^{1,2}$ and do not fit patterns of Mendelian segregation or assortment. Reasons for this departure from Mendelian predictions include the presence of genetic and/or phenotypic heterogeneity with contributions from low-penetrant, common alleles, environmental factors that are often unknown or immeasurable, ${ }^{3}$ and epistasis involving an interaction among an unknown number of genes. The absence of clearly defined phenotypes also contributes to this departure.

Many psychiatric disorders have been termed complex genetic traits. Support for this notion comes from several genetic-epidemiological approaches demonstrating the significant contribution of genetics (major genes or polygenes) embedded in a complicated environmental and cultural network. ${ }^{4}$ This interaction among genes, environment, and cultural inheritance has been dissected by genetic-epidemiological studies using complex segregation analysis, to test the likelihood of involvement of major genes (Mendelian inheritance), environment, and cohort (randomness) effects acting alone or

From the ${ }^{1}$ Department of Neurology, Children's National Medical Center, Washington, DC; ${ }^{2}$ Medical Genetics Branch, National Human Genome Research Institute, National Institutes of Health, Department of Health and Human Services, Bethesda, Maryland.

${ }^{*}$ Both authors contributed equally to this review.

Maximilian Muenke, Medical Genetics Branch, National Human Genome Research Institute, National Institutes of Health, 10 Center Drive-MSC 1852, Building 10, Room 10C103, Bethesda, MD 20892-1852.

Received: October 31, 2003.

Accepted: November 19, 2003.

DOI: 10.1097/01.GIM.0000110413.07490.0B as part of mixed models. This has been reported for a number of psychiatric disorders (Table 1).

\section{ATTENTION-DEFICIT/HYERACTIVITY DISORDER (ADHD): OVERVIEW}

ADHD has been considered a complex genetic trait based upon a phenotype ranging from mildly to severely affected and familial clustering without clearly recognizable Mendelian segregation. The effect of complex epistasis or pleiotropy acting in common with the environment may explain its high comorbidity with other disorders. Thus, the same gene or genes may be associated with different and concurrent phenotypes. ${ }^{5,6}$

Comorbidity of ADHD has been shown with depression, anxiety, oppositional disorder in childhood, conduct disorder, alcohol and substance abuse during adolescence, antisocial personality disorder, alcoholism, and substance dependence during early adulthood. ${ }^{7-11}$ Biological causes have been strongly implicated in the etiology of ADHD: (1) this disorder has been shown to follow Mendelian patterns in some families that have been used for linkage and segregation studies ${ }^{12-15}$; (2) brain abnormalities that have been noted in magnetic resonance imaging (MRI) studies, single photon emission computed tomography (Table 2); and (3) neurophysiological studies (heart rate deceleration, electroencephalogram amplitude of response to stimulation, and habituation on evoked responses of ADHD patients). ${ }^{16-18}$ These findings, when taken together, provide increasing support for the concept of ADHD as a neuropsychiatric condition or set of conditions with biological causes. 
Table 1

Complex segregation analysis for different psychiatric conditions

\begin{tabular}{|c|c|c|c|c|}
\hline Disorder or phenotype & Genetic effect & $\begin{array}{c}\text { Multifactorial effects } \\
\text { (environment plus polygenes) }\end{array}$ & Cohort effects & Ref. \\
\hline Bipolar disorder & Polygenic or oligogenic & Yes & & 120 \\
\hline Bipolar disorder & Complex familial effects & & & 121 \\
\hline Schizophrenia and auditory P300 latency & $\begin{array}{l}\text { Major autosomal gene plus a second } \\
\text { modifier locus }\end{array}$ & Yes & & 122 \\
\hline Schizophrenia & Major autosomal recessive gene & Yes. This model was parsimonious & $\begin{array}{l}\text { Yes, } 11 \% \text { of the } \\
\text { variance }\end{array}$ & 123 \\
\hline Schizophrenia & Major autosomal gene & $\begin{array}{l}\text { Yes, great environmental } \\
\text { component }(93.12 \%)\end{array}$ & & 124 \\
\hline Obsessive compulsive disorder (OCD) & $\begin{array}{l}\text { Major autosomal-dominant gene } \\
\text { (with a higher penetrance for } \\
\text { females) }\end{array}$ & No & No & 125 \\
\hline Tourette syndrome & Major autosomal gene & No & No & 126 \\
\hline Tourette syndrome & Major autosomal gene & Yes & No & 127 \\
\hline $\mathrm{ADHD}$ & $\begin{array}{l}\text { Major autosomal codominant- } \\
\text { dominant gene }\end{array}$ & No & No & 12,13 \\
\hline $\mathrm{ADHD}$ & Major autosomal codominant gene & No & No & 14 \\
\hline ADHD & Major autosomal gene & Yes & No & 15 \\
\hline
\end{tabular}

\section{CLINICAL PHENOTYPE}

\section{ADHD phenotype as a categorical trait}

Attention deficit and hyperactivity, respectively, has been described by the German physician, Heinrich Hoffmann, in 1845 in two boys he called "Johnny Look-in-the Air" and "Fidgety Philip." 19 In 1902, George Still, MD, delivered a series of lectures in which he described the lack of "moral control" among children without noted physical impairments. ${ }^{20}$ Historically, a series of different names, including "minimal brain damage syndrome," "minimal brain dysfunction," and "hyperkinetic reaction of childhood" were used to described the disorder that we know today as attention deficit/hyperactivity disorder. ${ }^{5}$ Early attempts to link attention deficits and behavioral disturbances to brain dysfunction were shaped by the experience of the encephalitis epidemic of 1917-1918. Children who survived the infection experienced subsequent problems including hyperactivity, personality changes, and learning difficulties. However, despite many years of research attempting to identify specific etiologic correlates of the disorder, no single cause has been identified and ADHD is currently best understood as a group of behavioral symptoms that reflect excessive impulsivity, hyperactivity, or inattention.

The first empirically based official set of diagnostic criteria for ADHD was delineated in the American Psychiatric Association's Diagnostic and Statistical Manual of Mental Disorders (DSM III) in 1980. ${ }^{21}$ Early focus on hyperactivity symptoms shifted toward attention and impulsivity symptoms later reflected in the changes taking place on the Diagnostic and Statistical Manual of Mental Disorders, Revised Third Edition (DSM III-R). ${ }^{21}$ The current classification criteria of the Diagnostic and Statistical Manual of Mental Disorders, Fourth Edi- tion (DSM IV)22 for ADHD allows diagnosis of subtypes as predominantly inattentive, predominantly hyperactive, or combined (Box 1). Although current diagnostic criteria including attention difficulties or distractibility are central to the disorder, the nomenclature suggests otherwise; attention is the main core deficit. These successive changes in diagnostic criteria reflect a combination of empirical research findings and expert committee consensus.

Taken as a whole, these criteria require an illness pattern that is enduring and has led to impairment. To make this diagnosis appropriately, the clinician must be familiar with normal development and behavior, gather information from several sources to evaluate the child's symptoms in different settings, and construct and appropriate differential diagnosis for the present complains. This helps, for example, to distinguish between children with ADHD from unaffected children whose parents or teachers are mislabeling normal behavior as pathological. The diagnostic criteria as used by appropriate examiners demonstrate high reliability on individual items and for overall diagnosis. ${ }^{23}$

Disturbances in attention and/or activity level are part of numerous genetic conditions, some of which are listed in Table 3. Thus, the diagnosis of "primary ADHD" is made when there is no evidence from the clinical history, physical examination, laboratory findings, or clinical criteria of another condition producing the clinical picture. ${ }^{24}$ Overall, ADHD is one of the best-researched disorders in medicine and the overall data on its validity are far more compelling than for many medical conditions. ${ }^{5,25-29}$

\section{ADHD phenotype as a continuous trait}

Studies of children with ADHD have generally used categorical definitions derived from DSM-IV ${ }^{22}$ and/or ICD-10. ${ }^{30} \mathrm{Un}$ - 
Table 2

Imaging and other studies implicating specific brain regions in ADHD

\begin{tabular}{|c|c|c|c|c|}
\hline Technique & Methodology & Structures affected & Additional findings & Ref. \\
\hline MRI & $\begin{array}{l}\text { Volumetric measurements of brain } \\
\text { structures; single measures and } \\
\text { longitudinal sample (5-18 years) }\end{array}$ & $\begin{array}{l}\text { Smaller total brain volume, special } \\
\text { caudate and cerebellum, right frontal } \\
\text { lobe }\end{array}$ & $\begin{array}{l}\text { Unmedicated patients had strikingly white } \\
\text { matter volumes compared with } \\
\text { medicated patients. No differences by } \\
\text { gender. Morphometric differences } \\
\text { correlated significantly with several } \\
\text { ratings of ADHD. }\end{array}$ & $128-131$ \\
\hline MRI & $\begin{array}{l}\text { Monozygotic twins discordant for } \\
\text { ADHD }\end{array}$ & $\begin{array}{l}\text { Affected twins have significantly } \\
\text { smaller caudate volumes than their } \\
\text { unaffected co-twin }\end{array}$ & & 132 \\
\hline MRI & $\begin{array}{l}12 \text { boys with ADHD and matched } \\
\text { control sample }\end{array}$ & $\begin{array}{l}\text { Decreased frontal lobe gray and white } \\
\text { matter volumes }\end{array}$ & $\begin{array}{l}\text { More than one subdivision of the frontal } \\
\text { lobes appears to be reduced in volume, } \\
\text { suggesting that the clinical picture of } \\
\text { ADHD encompasses dysfunctions } \\
\text { attributable to anomalous development } \\
\text { of both premotor and prefrontal } \\
\text { cortices. }\end{array}$ & 133 \\
\hline MRI & $\begin{array}{l}\text { Adult patients with ADHD } \\
\text { compared with controls }\end{array}$ & $\begin{array}{l}\text { Significant reduction of the volume of } \\
\text { the left OFC in patients with ADHD }\end{array}$ & Unmedicated adults patients & 134 \\
\hline MRI & $\begin{array}{l}\text { ADHD children compared with } \\
\text { normal control }\end{array}$ & $\begin{array}{l}\text { Smaller right frontal region, smaller } \\
\text { corpus callosum (genu-splenium) }\end{array}$ & $\begin{array}{l}\text { Reverse } \mathrm{L}>\mathrm{R} \text { pattern of asymmetry of the } \\
\text { head of caudate in ADHD children. }\end{array}$ & 135,136 \\
\hline f-MRI & go/no-go task & Frontostriatal circuits & $\begin{array}{l}\text { ADHD children do not activate } \\
\text { frontostriatal regions in the same } \\
\text { manner as normally developing } \\
\text { children, but rather rely on a more } \\
\text { diffuse network of regions, including } \\
\text { posterior and dorsolateral prefrontal } \\
\text { regions }\end{array}$ & 137 \\
\hline f-MRI & $\begin{array}{l}\text { Go/no-go task with and without } \\
\text { methylphenidate }\end{array}$ & $\begin{array}{l}\text { ADHD children had greater frontal } \\
\text { activation on one task and reduced } \\
\text { striatal activation on the other task }\end{array}$ & $\begin{array}{l}\text { MPH increased frontal activation to an } \\
\text { equal extent in both groups, but it } \\
\text { increased striatal activation in ADHD } \\
\text { children but reduced it in healthy } \\
\text { children. }\end{array}$ & 138 \\
\hline $\begin{array}{l}\text { QEEG } \\
\text { (Quantitative } \\
\text { EEG) }\end{array}$ & $\begin{array}{l}\text { QEEG with eyes open during } \\
\text { Continuous Performance Task }\end{array}$ & $\begin{array}{l}\text { ADHD children showed increased slow } \\
\text { cortical activity mainly over frontal } \\
\text { areas and decreased fast cortical } \\
\text { activity }\end{array}$ & $\begin{array}{l}\text { These findings may indicate a different } \\
\text { arousal level in children with ADHD }\end{array}$ & 139 \\
\hline $\begin{array}{l}\text { SPECT-99mTc- } \\
\text { HMPAO }\end{array}$ & $\begin{array}{l}40 \text { children ADHD compared with } \\
17 \text { control }\end{array}$ & $\begin{array}{l}\text { Decreased cerebral blood flow in right } \\
\text { lateral prefrontal cortex, right middle } \\
\text { temporal both orbital prefrontal } \\
\text { cortex and both cerebellar cortex }\end{array}$ & $\begin{array}{l}\text { ADHD group showed increased blood flow } \\
\text { in some parietal and occipital regions }\end{array}$ & 140 \\
\hline
\end{tabular}

der these diagnostic systems, individuals are classified as affected if they meet a specific number of criteria, which are determined with reliable and validated psychiatric instruments. However, multiple lines of evidence suggest the relationship between risk genes and the symptoms of ADHD is likely to be pleiotropic, i.e., that the same gene or genes may be associated with different and concurrent phenotypes. ${ }^{31}$ Similarly, several studies have suggested that ADHD represents one extreme of the quantitative manifestation of normal behavior. ${ }^{32-35}$ Based on these considerations, Curran and colleagues $^{35}$ recently concluded that "both categorical (diagnostic) and continuous (quantitative trait) approaches to phenotypic dimension are valid and may be complimentary in molecular genetic studies on ADHD." 35(p86)

Among statistical approaches, latent class analysis, i.e., a categorical approach to ADHD applied to parent report rating scales, has identified the presence of six to eight latent classes underlying the ADHD phenotype in contrast to the three DSM-IV ADHD categorical subtypes. These findings suggest the presence of more subtle independent groups within the ADHD phenotype than those advocated by the classical categorical classification. ${ }^{36,37}$

\section{Natural history and comorbidity of ADHD}

Longer-term follow-up studies of children with ADHD as well as studies of symptomatic adults who have been retrospectively diagnosed with childhood ADHD show that there is symptomatic persistence of ADHD into adulthood in many cases. On average, symptoms diminish by about $50 \%$ every 5 years between ages 10 to 25 years. Hyperactivity itself declines more quickly than impulsivity or inattentiveness. ${ }^{38,39}$ On the other hand, a number of psychiatric conditions co-occur with 


\begin{tabular}{|ll|}
\hline \multicolumn{2}{|c|}{$\begin{array}{c}\text { Box } \mathbf{1} \\
\text { Diagnostic criteria: Behavioral findings often present in individuals with } \\
\text { ADHD }\end{array}$} \\
\hline Inattention & Hyperactivity/Impulsivity \\
\hline $\begin{array}{l}\text { Careless errors, inattentive to } \\
\text { detail }\end{array}$ & Fidgets or squirms \\
$\begin{array}{l}\text { Sustains attention poorly } \\
\text { Appears to not be listening }\end{array}$ & Cannot stay seated \\
$\begin{array}{l}\text { Follows through poorly on } \\
\text { obligations }\end{array}$ & $\begin{array}{l}\text { Restless (subjective in } \\
\text { adolescents) }\end{array}$ \\
$\begin{array}{l}\text { Disorganized } \\
\text { Avoids or dislikes sustained } \\
\text { mental effort }\end{array}$ & Loud, noisy \\
Looses needed objects & Always "on the go" \\
Easily distracted & Blurts oxcessively \\
Forgetful & Impatient \\
\hline Modified from DSM IV. ${ }^{22}$ & Intrusive \\
\hline
\end{tabular}

ADHD. Between $10 \%$ and $20 \%$ of children with ADHD have mood disorders, $20 \%$ have conduct disorders, ${ }^{7}$ and $30 \%$ to $45 \%$ of patients with ADHD also have oppositional defiant disorder (ODD). Conversely, between $61 \%$ and $67 \%$, patients with ODD have ADHD. ${ }^{40,41}$ Furthermore, bipolar disorder is being increasingly recognized in ADHD. ${ }^{42-49}$

Only about $7 \%$ of those with ADHD have tics or Tourette syndrome, but $50 \%$ to $90 \%$ of individuals with Tourette syndrome have $\mathrm{ADHD},{ }^{50-54}$ raising questions about common etiologic mechanisms. Learning disorders (especially reading disorders) and subnormal intelligence also are increased in the total population of those with ADHD and vice versa. ${ }^{55,56}$ Overall, perhaps as many as $65 \%$ of children with ADHD will have one or more comorbid conditions, although their presence will not be recognized with appropriate questioning and evaluation. ${ }^{57-59}$ In general, when ADHD is untreated there is a gradual accumulation of adverse processes and events that increase the risk of serious psychopathology later in life. ${ }^{60}$

The relation between substance abuse disorder and ADHD is complex. Children with ADHD who do not have comorbid conditions have a risk of substance use that is not different from children without ADHD up to the age of about 14 years. ${ }^{61}$ The risk of developing substance abuse disorder when ADHD is present increases in adolescents and the risk ratio increases further in adulthood, regardless of whether there is comorbidity. ${ }^{38,62}$ Persistence of ADHD symptoms and family history of both ADHD and substance use disorders are risk factors for the development of substance abuse. ${ }^{38}$ Highly potent risks for substance abuse disorder are the presence of comorbid conduct disorder or bipolar disorder.9,63-65 One prospective study, which followed an ADHD cohort over an average of 16 years along with a matched control group found an 11-fold increase in on-going ADHD symptoms (11\% vs. 1\%), a 9-fold increase in antisocial personality disorder ( $18 \%$ vs. $2 \%)$, and a 4 -fold higher rate of drug use disorder (16\% vs. $4 \%) .{ }^{66}$

Finally, current clinical evidence suggests that there are two nosologically and clinically distinct categories of ADHD: one category correlates with conduct disorder, and the other one correlates with learning disabilities. ${ }^{8,67}$ The subset associated with conduct disorder appears to be a particularly powerful target group for molecular genetic analyses because of the extremely elevated recurrence risk in siblings. ${ }^{62,68}$

\section{EPIDEMIOLOGY OF ADHD}

Epidemiological research in ADHD has been hampered by difficulties involved in the diagnosis of ADHD and the numerous definitional changes that have taken place in the past 20 years. It is clear that individuals with ADHD comprise a heterogeneous population sharing a cluster of symptoms. The frequently subjective definition as well as the lack of available biological markers makes an adequate comparison of epidemiological studies difficult. Despite these difficulties, rigorous estimates indicate that ADHD has been described almost everywhere around the world. Community studies have estimated prevalence ranging between $1.7 \%$ and $21 \%$, depending upon the population and the diagnostic methods (Table 4).

These results suggest that across populations under diverse geographic, racial, ethnic, and socioeconomic conditions there exists a sizable percentage of school-aged children with ADHD. Furthermore, because the evolution of criteria from DSM III to DSM IV have broadened the limits of case definition, more children appear to be affected. ${ }^{69}$ This is largely a function of the increased emphasis on attentional problems as opposed to a more narrow focus on hyperactivity in earlier diagnostic sets. As a result, girls have been diagnosed as having ADHD more frequently than they were in the past. ${ }^{70,71}$

Caution must be used when comparing epidemiological data from different studies, because diverse types of instruments and questionnaires have been used in different epidemiological trials and the DSM-IV definition of impairment is operationally vague. These issues are a source of subjective knowledge to the clinical evaluator when deciding the affection status. Furthermore, random selection of the sample versus "volunteer" participation could introduce a relevant bias in the estimation of epidemiological parameters. For example, stigmatization of ADHD patients and their families may lead to an underestimation of its prevalence. On the other hand, patients already under medication will exhibit less severe symptoms at the time of the screening.

Differences in perception between parents and teachers should also be considered in ADHD studies. Teacher reports may be influenced by factors such a class size, teacher training, or disciplinary aptitudes and practices. Although the DSM IV age criterion to establish the diagnosis is 7 years, new studies are reporting patients with diagnosis done after 7 years, in particular those cases exhibiting the inattentive type. ${ }^{72}$ Associated limitations involve the presence of comorbid and underlying conditions that mimic in part ADHD, especially in studies us- 
Table 3

Selected genetic disorders associated with ADHD

\begin{tabular}{|c|c|c|c|c|}
\hline Genetic Condition & Neuroanatomic alteration & Neuropsychological impairments & Gene and/or biochemistry & Ref. \\
\hline Neurofibromatosis I & Aqueductal stenosis, hydrocephalus & $\begin{array}{l}30 \% \text { learning disabilities, } 10 \% \text { mild } \\
\text { mental retardation }\end{array}$ & $\begin{array}{l}\text { Caused by mutations in the } \\
\text { neurofibromin gene (NF1) }\end{array}$ & 141 \\
\hline $\begin{array}{l}\text { Varying degrees of } \\
\text { Holoprosencephaly } \\
\text { (HPE) associated } \\
\text { with mild features }\end{array}$ & $\begin{array}{l}\text { Microcephaly and general abnormalities } \\
\text { involving telencephalic and } \\
\text { diencephalic structures }\end{array}$ & $\begin{array}{l}\text { Impaired executive functions, attention } \\
\text { problems }\end{array}$ & $\begin{array}{l}\text { HPE is caused most frequently by } \\
\text { mutations in SHH, but also in } \\
\text { SIX3, TGIF and ZIC2 }\end{array}$ & 142 \\
\hline Turner Syndrome & Unknown & $\begin{array}{l}\text { Girls with Turner syndrome have } \\
\text { significantly more problems with } \\
\text { social relationships and school } \\
\text { progress and were more likely to } \\
\text { meet criteria for ADHD than control } \\
\text { girls }\end{array}$ & Complex & $143-145$ \\
\hline Williams Syndrome & $\begin{array}{l}\text { In the mice, haploinsufficiency for } \\
\text { Cyln2 encoding CLIP-115, located in } \\
\text { the } 1.6 \mathrm{Mb} \text { common deletion leads to } \\
\text { brain abnormalities, hippocampal } \\
\text { dysfunction and particular deficits in } \\
\text { motor coordination. Absence of } \\
\text { CLIP-115 also leads to increased } \\
\text { levels of CLIP-170 (a closely related } \\
\text { cytoplasmic linker protein) }\end{array}$ & $\begin{array}{l}\text { Mental retardation (average IQ 56), } \\
\text { relative sparing of language, poor } \\
\text { visual-motor integration (Range } \\
\text { 41-80), hypersensitivity to sound, } \\
\text { attention deficit disorder, cocktail } \\
\text { party personality }\end{array}$ & $\begin{array}{l}\text { Contiguous gene syndrome with } \\
\text { haploinsufficiency, of multiple } \\
\text { genes including Elastine (ELN), } \\
\text { LIM kinase-1 (LIMK1), and RFC2 }\end{array}$ & 146,147 \\
\hline Fragile X Syndrome & $\begin{array}{l}\text { Cortical and sub-cortical grey matter } \\
\text { alterations (caudate, vermis), } \\
\text { abnormalities in dendritic } \\
\text { arborization of the cortex, alterations } \\
\text { in volume of caudate nucleus and in } \\
\text { the cerebellar vermix. }\end{array}$ & $\begin{array}{l}\text { Wide range of variability in mental } \\
\text { retardation, ADHD symptoms } \\
(74 \%), \text { ODD, impaired executive } \\
\text { function, viso-spatial abilities, } \\
\text { visuomotor coordination }\end{array}$ & $\begin{array}{l}\text { Unclear, possible several } \\
\text { neurotransmitters affected. }\end{array}$ & 148 \\
\hline $\begin{array}{l}\text { Smith-Magenis } \\
\text { Syndrome }\end{array}$ & $\begin{array}{l}\text { Ventriculomegaly, dysgenesis of the } \\
\text { cerebellar vermis overlapping with } \\
\text { features of Joubert Syndrome }\end{array}$ & $\begin{array}{l}\text { Speech delay, mental retardation (IQ } \\
\text { 20-78), behavioral problems, self- } \\
\text { destructive behavior, sleep } \\
\text { disturbance, hyperactivity, } \\
\text { peripheral neuropathy, decreased } \\
\text { pain sensitivity }\end{array}$ & $\begin{array}{l}\text { Caused by an interstitial deletion of } \\
17 \mathrm{p} 11.2\end{array}$ & $149-153$ \\
\hline Phenylketonuria & Prefrontal cortex dysfunction & Altered executive functions & $\begin{array}{l}\text { Alterations of the Dopamine } \\
\text { metabolic pathway as } \\
\text { consequence of PAH alteration }\end{array}$ & $154-158$ \\
\hline $\begin{array}{l}\text { Fetal alcohol } \\
\text { syndrome }\end{array}$ & $\begin{array}{l}\text { D1 receptors in mesolimbic dopamine } \\
\text { system }\end{array}$ & $\begin{array}{l}\text { Difficulties in learning, speed } \\
\text { information, attentional, working } \\
\text { memory and self regulation } \\
\text { processes }\end{array}$ & $\begin{array}{l}\text { Several neurotransmitters are } \\
\text { affected including dopamine, } \\
\text { serotonine norepinephrine, } \\
\text { glutamate, GABA, histamine }\end{array}$ & 159 \\
\hline $\begin{array}{l}\text { Deletion } 22 \mathrm{q} 11.2 \\
\text { syndrome }\end{array}$ & $\begin{array}{l}\text { Abnormal left/right pattern of caudate } \\
\text { nucleus (also seen in ADHD) }\end{array}$ & $\begin{array}{l}13 \text { of } 20 \text { children tested have ADHD, } \\
\text { mainly inattentive or combined type } \\
\text { and/or autism spectrum problems }\end{array}$ & $\begin{array}{l}\text { Suspected the involvement of } \\
\text { COMT, contained in the deleted } \\
\text { region }\end{array}$ & $160-162$ \\
\hline $\begin{array}{l}\text { Traumatic Brain } \\
\text { Injury (TBI) }\end{array}$ & $\begin{array}{l}\text { According with severity, lesion } \\
\text { localization and time. Frontal lobe } \\
\text { and basal ganglia lesions specially } \\
\text { associated with ADHD phenotype }\end{array}$ & $\begin{array}{l}\text { ADHD symptoms, depression, } \\
\text { executive dysfunction, memory and } \\
\text { behavioral alterations }\end{array}$ & $\begin{array}{l}\text { Disruption of frontobasal ganglia } \\
\text { pathways among other alterations }\end{array}$ & $163-166$ \\
\hline
\end{tabular}

ing rating scales or structured diagnostic interviews, rather than clinician-based semistructured interviews.

\section{GENETICS OF ADHD}

\section{Family-based and segregation studies}

Over the past decade, twin, adoption, family, and association studies have shown that genetic factors contribute to the etiology of ADHD. Genetic studies in twins indicate a substantially higher genetic (additive) contribution to phenotypic variation, reaching 0.91 , even when shared environmental factors have been excluded. ${ }^{32,33}$ Adoption studies have also confirmed that genetics rather than shared environment cause familial clustering of ADHD. ${ }^{73}$ Family studies have confirmed the observation of increased recurrence risk by comparing the ratio of the prevalence of $\mathrm{ADHD}$ in various kinds of relatives to the population prevalence using the $\lambda$ statistic. ${ }^{62,74,75}$

Complex segregation analysis of 257 nuclear families ascertained from Caucasian, non-Hispanic, male ADHD probands 
Table 4

Prevalence of ADHD in different populations using different diagnostic instruments

\begin{tabular}{|c|c|c|c|c|c|}
\hline Instruments & Sample & $\begin{array}{l}\text { Ethnicity-population } \\
\text { characteristics }\end{array}$ & Additional comments & Prevalence & Ref. \\
\hline DSMIV parents and teachers & $\begin{array}{l}\text { School population; Not } \\
\text { randomly selected }\end{array}$ & White $80 \%$ & $\begin{array}{l}\text { Special screening was done } \\
\text { to children already on } \\
\text { medication. }\end{array}$ & $12 \%$ & 72 \\
\hline DISC module for ADHD & & Afro-Americans 15\% & $\begin{array}{l}\text { Concordance between } \\
\text { parents and teachers was } \\
\text { required to be included. }\end{array}$ & & \\
\hline
\end{tabular}

$\begin{array}{ll}\text { DSMIV checklist parents } & \begin{array}{c}\text { Randomized sample from } \\ \text { and teachers. }\end{array} \\ \begin{array}{l}\text { Confirmation of cases by } \text { igh and low } \\ \text { individual evaluation }\end{array} & \text { socioeconomic classes } \\ & \text { (Colombia, South } \\ & \text { America) }\end{array}$

DSMIV checklist parents and teachers.

Confirmation of cases by individual evaluation

Clinical interview, IQ scales

school, all children from grade $1-5$

Randomized sample from
Hispanic 5\%

Boys $21.8 \%$, Girls $10.9 \%$

$17.1 \%$

Colombians of Hispanic origin

Brazil

$17.1 \%$

168 schools in one city (4-17 Colombia)

$11.5 \%$ for "clean ADHD” years) (Manizales,

\section{Clean cases prevalence. Inattentive type $4.8 \%$, combined type $6.4 \%$, hyperactivity type $0.3 \%$}

Bangkok, Thailand

Raven's progressive matrices test for estimation of intellectual function. Conners scales. Positive cases with Conners, were evaluated with DSMIV checklist

DSMIII-R for parents, child and teacher $(6-11 \mathrm{y})$ and parents, and child (12-14)

DSMIII-R DSMIV for teachers

DSMIII

DSMIII-R, DSMIV for teachers

DSMIII-R for teachers (included in a Conners like questionnaire)
433 children from 1-6 grades $85 \%$ children participated in the study

2400 representative sample from throughout Quebec

8258 children from kindergarten to fifth grade in middle Tennessee county
$6.9 \%$ population is AfricanAmerican
$17.2 \%$ population below poverty level
No specific for $\mathrm{ADHD}$, symptoms. It included borderline and mild mental retardation as well as developmental coordination disorder

The Quebec Child Mental
Health Survey

Anxiety behavioral, academicals problems and depression as well as treatment with stimulant medication was included in questionnaires
$19.9 \%$ according with parents $15.8 \%$ according to the child

DSMIII-R 11.4\%, increment of $57 \%$ of children diagnosed with ADHD with DSMIV checklist
Most of them primary German-speaking. One teacher from each grade level 1-4 was volunteered
ODD and CD were also included in evaluation in this study

DSMIII prevalence $9.6 \%$ urban public schools from 44 classroom teachers in Regensburg, Germany

931 nationwide sample kinder-8th grade
DSMIV prevalence $17.8 \%$

$18.2 \%$ if they score the second 174 highest and the highest stem in the checklist or $4 \%$ if they scored only the highest stem ages 6 to 17 using the mixed model and a logistic regression model demonstrated that the best fitting model was that of a major codominant gene $\mathrm{e}^{15}$ (Table 1). These results were confirmed in a complex segregation analysis by fitting class $\mathrm{A}$ and class $\mathrm{D}$ regres- sive models on 495 nuclear families that were ascertained from fathers who were probands in a longitudinal family/high-risk study of substance abuse. ${ }^{14}$ From these 495 nuclear families, a subgroup of 130 nuclear families was selected in which at least one 
Table 5

Simulation study to determine the number of ADHD affected sibpairs needed to detect linkage assuming than $40 \%$ of families are linked to the same locus, $80 \%$ power, and the marker informativeness is 1.0

\begin{tabular}{ccc}
\hline$\lambda_{\mathrm{S}}$ & \% of linked families & \# of sibpairs \\
\hline 2.5 & 40 & 1110 \\
3.7 & 40 & 712 \\
5.0 & 40 & 575 \\
\hline
\end{tabular}

of the members of the nuclear family met the DSM-III-R diagnostic criteria for ADHD. The model fitting the data best was that of a sex-dependent Mendelian codominant model.

In the third complex segregation analysis under the unified model applied to 53 nuclear families from a genetic isolate (the Paisa community in Colombia, South America), the following models were rejected: cohort effect (noninheritance), multifactorial inheritance, recessive major gene, nonmajor gene component, and nontransmission of a major gene. ${ }^{13}$ In contrast, dominant and codominant major gene models and a nonmultifactorial component could not be rejected. Taken together, the model fitting these data best was that of a major dominant gene without the existence of multifactorial effects. This putative major gene explained more than $99.993 \%$ of ADHD phenotypic variance, which suggests a low contribution of environmental factors to the ADHD phenotype.

Although these three studies were performed in different populations, using different schemes of ascertainment, and with various methods to test models of inheritance, they converge in explaining the predisposition to ADHD as the consequence of a major gene or genes. These major genes exhibiting Mendelian segregation have an estimated penetrance of about
$50 \%$ and differential sex liability. Purely environmental or cultural causes were largely excluded in all cases.

\section{Searching for ADHD genes}

Like all major psychiatric disorders, ADHD is considered genetically complex, in that transmission does not follow classical Mendelian models. Based on influential mathematical simulations, ${ }^{74,76}$ the recommended strategy for mapping genes that convey susceptibility to ADHD and other psychiatric disorders has consisted of collecting large samples of affected sibling pairs, family-based parent-proband "trios," and large samples of cases and controls. 62,77 This recommendation follows estimations of lambda $(\lambda)$ or magnitude of the risk ratios computed by dividing the affection rate among each relative type to the rate of affection in the population. ${ }^{74,76}$ Lower $\lambda$ values may be due to a variety of factors such as oligogenic transmission, genetic heterogeneity, phenocopies, and low penetrance. ${ }^{62}$ In the case of ADHD, $\lambda$ values from ADHD family studies are consistently low, ranging from two to three for the risk of siblings and two to eight for the risk to parents. ${ }^{62}$ Assuming different values for $\lambda$, our simulation study estimates that approximately $1000 \mathrm{ADHD}$ affected sibpairs are necessary to detect linkage for a trait as heterogeneous as ADHD (Table 5). In families with individuals who have ADHD that persists into adulthood, or ADHD with comorbid conditions such as conduct and/or bipolar disorders, $\lambda$ could reach values $>20$. Thus, a smaller number of sibpairs could be used to detect linkage. ${ }^{62}$

We have initiated sibpair studies in the US population. Two other groups have published data from their own sibpair studies, reviewed later ${ }^{78-80}$ In addition, however, we have analyzed data from large families from a genetic isolate (the Paisa community in Colombia, South America). Extensive descriptions

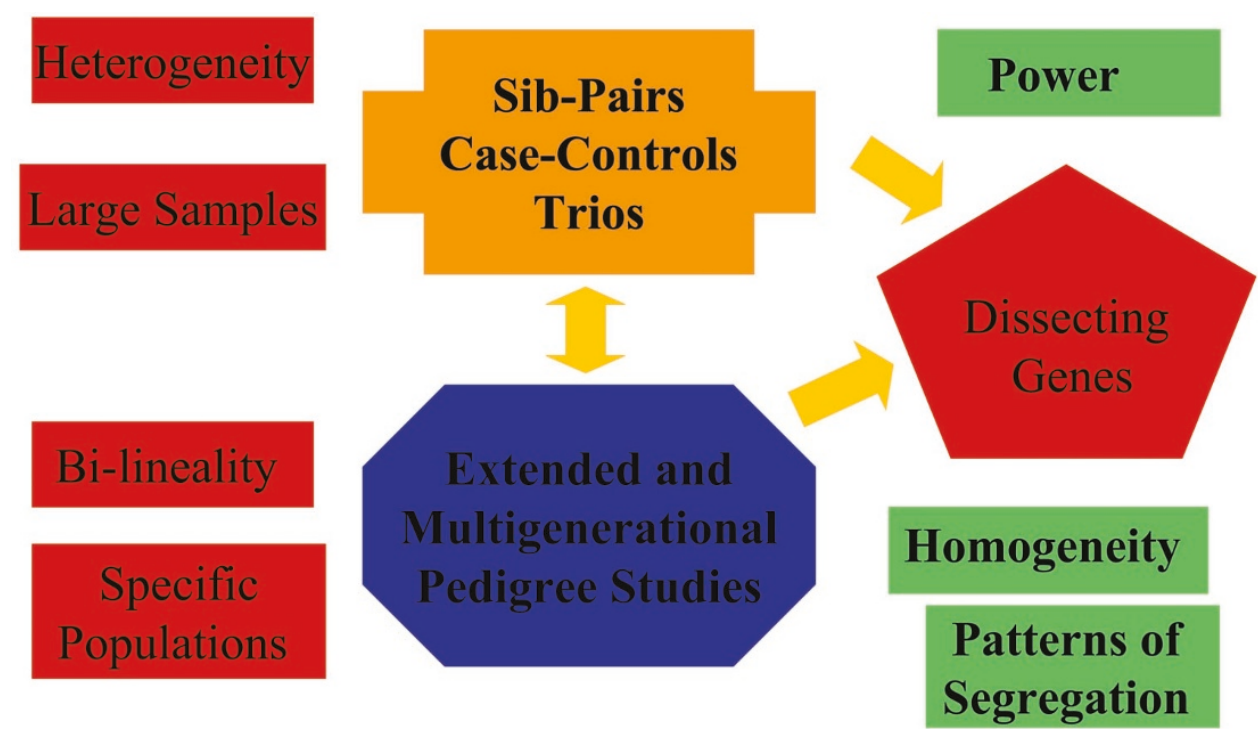

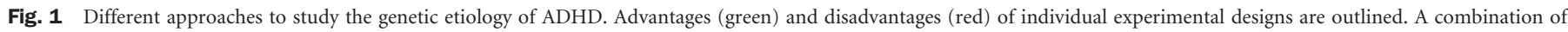
different study designs (orange and blue) is predicted to be most successful in identifying genes that contribute to ADHD. 


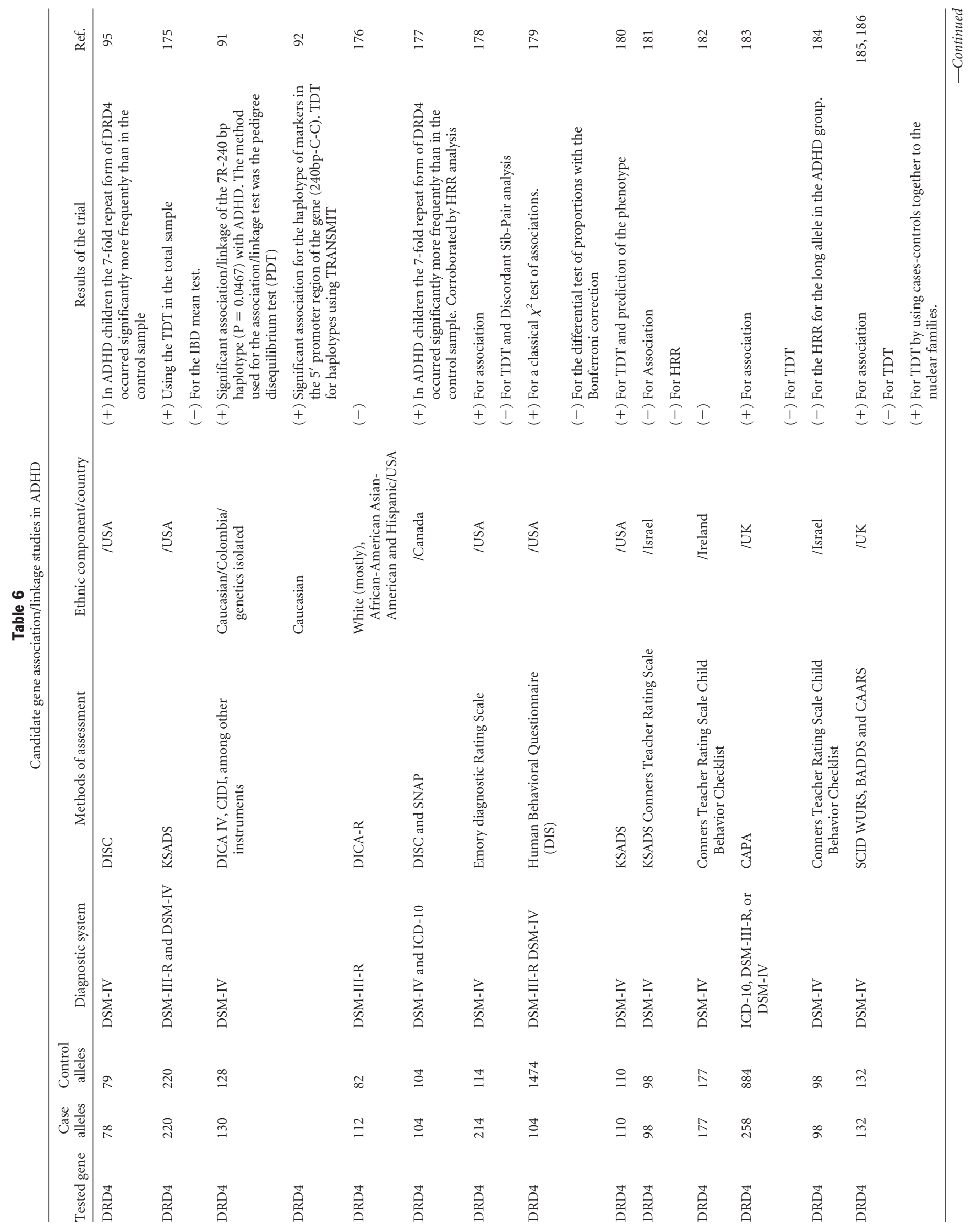


Genetics of ADHD: Complex or simple?

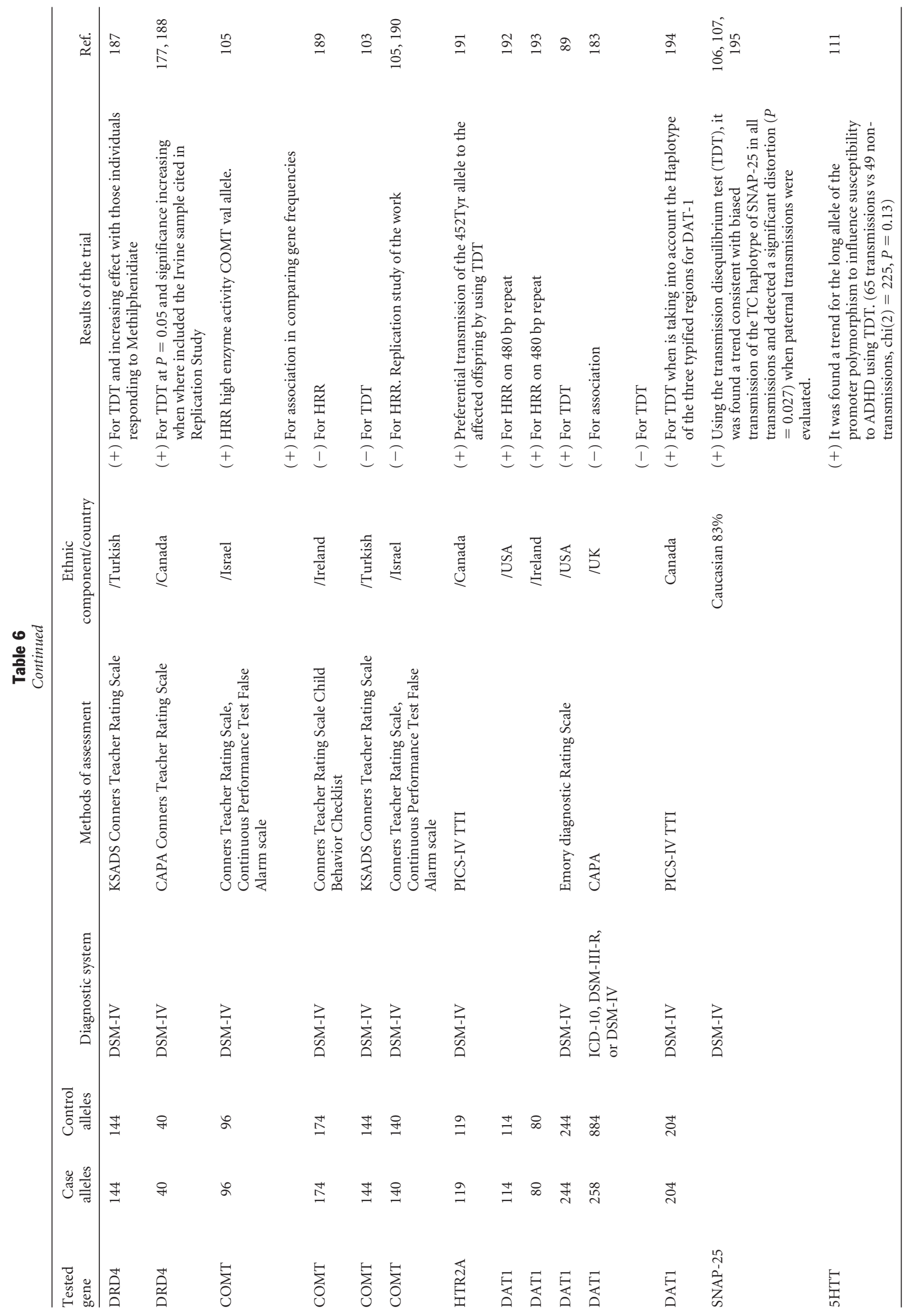


of the Paisas have been published elsewhere. ${ }^{81-83}$ Briefly, the Paisa community, which contained over 4,000,000 inhabitants in 1998, is located between the Central and Western branches of the Andes Mountains and was geographically isolated from the 16th until the latter half of the 20th century.

The Paisas are historically descended largely from Spaniards, Sephardic Jews, and Basques. ${ }^{81-84}$ Taking advantage of the particularly large families that have generally been the norm in the Paisa community until recently, we have recruited multigenerational extended pedigrees. Based on simulations, we found that these extended families provide extraordinarily high estimates of statistical power for locating major susceptibility genes. ${ }^{12}$ Simulations of statistical power in these large, multigenerational, densely affected families have also demonstrated exceptionally good power to detect linkage with expected LOD (logarithm of the odds) scores $>14$ for recombination fractions of 0.1 or less, and expected LOD scores $>5.87$ even if genetic heterogeneity were present in $50 \%$ of the families. ${ }^{12}$ Thus, based on both the psychiatric characteristics of the participants, as well as structural genetic factors, we believe that these families will be highly informative regarding major susceptibility genes for ADHD, possibly in association with conduct disorder. We predict that studying a combination of sibpairs, cases and controls, in addition to extended, multigenerational families from a genetic isolate, will be most successful in eventually identifying ADHD susceptibility genes: advantages (in green) and disadvantages (in red) of these different approaches are shown in Figure 1.

\section{Candidate gene approaches}

Because of the cumulative evidence supporting the presence of major genes conveying susceptibility to ADHD, different genetic approaches involving family-based and case-control studies have been performed with the goal of detecting association and/or linkage to genomic regions or candidate genes. Based on theoretical considerations, animal models, and the remarkable effectiveness of stimulant treatment, many candidate genes have been selected from the dopaminergic and other pathways, some of which show real associations, but with small genetic effect ${ }^{85,86}$ (Table 6).

Tested genes with significant allelic association and linkage to ADHD include the dopamine transporter (DAT), which codes for the main molecular target of stimulant medications such as methylphenidate, ${ }^{87-90}$ and the dopamine receptor D4 (DRD4). ${ }^{90-95}$ In general, genes involved in the metabolic pathway of monoamines have shown positive as well as negative results of association/linkage to ADHD. These genes/proteins include dopamine-beta-hydroxylase $(\mathrm{DBH})$ that catalyze the conversion of dopamine to norepinephrine, ${ }^{96-99}$ the monoamine oxidase A (MAOA), ${ }^{100,101}$ and the catecholaminemethyl transferase (COMT). ${ }^{102-105}$

Another neurotransmitter tested by the candidate gene approach is SNAP-25, a gene encoding a synaptic vesicle docking protein known to play a role in the hyperactivity observed in the Coloboma mouse strain. ${ }^{106-110}$ The results have been consistent with biased transmission of a specific haplotype of
SNAP-25 in all transmissions and detected a significant distortion when paternal transmissions were evaluated. ${ }^{106}$

Because reduced central serotonergic activity has been implicated in poor impulse regulation and aggressive behavior in animals, adults, and also young children, polymorphisms of serotonergic related genes, such as the serotonin transporter promoter SLC6A4 polymorphism, have been reported associated/linked with ADHD by several groups. ${ }^{111,112}$ Polymorphisms in the 5-hydroxytriptamine 2 A receptor (5-HT2A) and the 5-hydroxytriptamine $1 \mathrm{~B}(5-\mathrm{HT} 1 \mathrm{~B})$ receptor genes have been similarly associated with ADHD. ${ }^{90}$

\section{Genome-wide searches}

In order to facilitate the search for potential major susceptibility genes, two independent groups have assembled sizable samples of affected siblings and have conducted genome-wide screens aimed at uncovering major risk genes for ADHD. ${ }^{78-80}$ The preliminary results from these genome-wide surveys resulted in LOD scores (put in numbers) and suggested several regions that may harbor one or more major risk genes for ADHD, particularly on chromosomes 7, 11, 12, 15, 16, and 17. The findings from these two studies do not overlap, indicating that genetic heterogeneity may represent a substantial obstacle to replication across samples, and to definitive gene mapping.

Our group has performed a genome-wide scan using the 16 extended and multigenerational families from the Paisa isolate. ${ }^{84}$ Two-point LOD score analyses were estimated using FASTLINK ${ }^{113}$ as implemented in LINKAGE. ${ }^{114}$ SIMWALK2 was used to obtain multipoint location scores, nonparametric linkage statistics and to reconstruct haplotypes. ${ }^{115}$ Two point analysis using a parametric model revealed LOD scores higher than 1.5 in individual families at chromosomes 8q12 (D8S1110, LOD score $=3.227), 11 \mathrm{q} 23.3(\mathrm{D} 11 \mathrm{~S} 1998, \mathrm{LOD}$ score $=2.62), 4 \mathrm{q} 13.2$ $(\mathrm{D} 4 \mathrm{~S} 2367, \mathrm{LOD}$ score $=2.56), 17 \mathrm{p} 11.2(\mathrm{D} 17 \mathrm{~S} 799, \mathrm{LOD}$ score $=$ 1.98), 12q23.2 (PAH, LOD score = 1.71), and 8p23.1 (D8S1130, LOD score $=1.66)$. The nonparametric analysis confirmed the parametric results. ${ }^{84}$ In the previous genome-wide scan, ${ }^{78,79}$ $17 \mathrm{p} 11$ and $11 \mathrm{q} 25$ were also implicated as suggestive regions containing genes conveying susceptibility to develop ADHD but our suggested regions on chromosomes 8 and 4 are novel. Observing LODs this high in individual families by chance is highly improbable based on the eLOD scores obtained when a nonlinked marker is simulated in these pedigrees. Furthermore, the empiric family-specific pattern of LODs throughout the genome scan for families $8,9,11$, and 14, suggest that these high LODs are not likely to be caused by chance because of the strong negative LODs observed throughout the genome. Taking these data together with other previous reports, it is reasonable to conclude that some of these regions may harbor risk genes contributing to susceptibility to ADHD. ${ }^{84}$

\section{CLINICAL APPLICATIONS}

\section{Family history}

Family history of ADHD has important implications not only for genetic studies, but also for the assessment and treat- 
ment of family members affected with this disorder. As mentioned previously, if a parent or sibling had ADHD, then the risk to a sibling is $25 \%$ to $30 \%$ based on Mendelian segregation and an estimated penetrance of $50 \%$ to $60 \%$. This needs to be taken into account when treatment plans are designed for children with ADHD. Furthermore, there is a high risk of other psychiatric comorbidities associated with ADHD, such as conduct disorder, alcohol, and/or drug abuse among others (see earlier). ADHD and its associated comorbidities can have a significant impact on family functioning. The family dynamic can be further influenced by a parent's psychiatric status. Minde and colleagues ${ }^{116}$ found that children with an ADHD parent had higher rates of psychopathology and higher risk of comorbidities. Family and marital functioning are impaired by the presence of an affected parent regardless the gender. In addition, a child's diagnosis of ADHD by itself has been shown to have an impact on family styles. For example, a higher frequency of disorganization and lack of cohesion is more frequently found in families of children with ADHD and emotional disorders. ${ }^{117}$

\section{Gene testing}

Although several genome-wide searches have identified chromosomal regions that are predicted to contain genes that contribute to ADHD susceptibility, to date no single gene with a major contribution to ADHD has been identified. Even though a number of genes have been associated with ADHD, these genes are at present more of academic interest than helpful for patient care. Thus, gene testing for ADHD is not available at this point in time. Similarly, MRI, EEG, evoked potentials, SPECT, and f-MRI are currently used only in research settings and are not recommended for routine evaluation of ADHD. However, occasional use of these diagnostic tools may be considered to rule out other neurological diagnosis that can mimic ADHD symptoms.

\section{Medication by ADHD subtypes}

Stimulant medications are widely recognized as the first line of treatment for ADHD. After substantial debate the superiority of these medications has been established over other interventions, such as antidepressants and behavioral techniques. In general, the successful rate of treatment for stimulant medications is between $70 \%$ and $90 \%$. However, important differences have been observed in response to medication according to ADHD subtype and associated comorbidity. For example, patients with the predominantly hyperactive-impulsive subtype as well as patients with comorbid conditions such as conduct disorder or oppositional defiant disorder have a higher rate of successful treatment than patients with the inattentive type or comorbid anxiety. In fact, over $80 \%$ of nonanxious children with ADHD responded to stimulants, whereas only $30 \%$ of the children with ADHD and anxiety benefited from the drug. ${ }^{118}$ In addition, patients with ADHD and anxiety had more adverse side effects than patients with ADHD alone. For children with ADHD and anxiety, psychological treatment in combination with stimulants has been shown to be the optimal treatment. ${ }^{119}$

\section{Counseling}

Although stimulant medication remains the most effective treatment, family counseling is an important part of successful treatment. Behavioral intervention and academic accommodations are necessary to ameliorate the significant impairment that can be associated with ADHD. Periodic review of the treatment plan is necessary to address developmental changes across the lifespan of an individual with ADHD.

\section{SUMMARY}

ADHD represents a phenotype for which prevalence, comorbidity, and outcome have been replicated in numerous analyses around the world. Neurobiological studies using MRI show specific abnormal structural patterns of cerebral structures. Furthermore, recently independent genetic studies have replicated results of association and linkage to different candidate genes and genomic regions that overlap with mental disorders such as autism and schizophrenia. All of these data together support a model that major genes exhibit epistasis and act on cerebral ontogeny and thus contribute to the genesis of ADHD, the most common behavioral disorder of childhood.

\section{ACKNOWLEDGMENTS}

We are grateful to Drs. Joan Bailey-Wilson, Kate Berg, F. Xavier Castellanos, and Christopher Sarampote for their input to this manuscript.

\section{References}

1. Witte JS, Elston RC, Schork NJ. Genetic dissection of complex traits. Nat Gene 1996;12:355-356

2. Elston RC. Introduction and overview: Statistical methods in genetic epidemiology. Stat Methods Med Res 2000;9:527-541.

3. Ober C, Abney M, McPeek MS. The genetic dissection of complex traits in a founder population. Am J Hum Genet 2001;69:1068-1079.

4. Asherson P, Curran S. Approaches to gene mapping in complex disorders and their application in child psychiatry and psychology. Br J Psychiatry 2001;179:122-128.

5. Castellanos FX, Tannock R. Neuroscience of attention-deficit hyperactivity disorder: the search for endophenotypes. Nat Rev Neurosci 2002;3:617-628.

6. Stevenson J, Pennington BF, Gilger JW, DeFries JC, Gillis JJ. Hyperactivity and spelling disability: testing for shared genetic aetiology. J Child Psychol Psychiatry 1993;34:1137-1152.

7. Biederman J, Newcorn J, Sprich S. Comorbidity of attention deficit hyperactivity disorder with conduct, depressive, anxiety, and other disorders. Am J Psychiatry 1991;148:564-577.

8. Biederman J, Faraone SV, Keenan K, Benjamin J, Krifcher B, Moore C et al. Further evidence for family-genetic risk factors in attention deficit hyperactivity disorder: Patterns of comorbidity in probands and relatives psychiatrically and pediatrically referred samples. Arch Gen Psychiatry 1992;49:728-738.

9. Biederman J, Wilens TE, Mick E, Faraone SV, Spencer T. Does attention-deficit hyperactivity disorder impact the developmental course of drug and alcohol abuse and dependence? Biol Psychiatry 1998;44:269-273.

10. Scahill L, Schwab-Stone M, Merikangas KR, Leckman JF, Zhang H, Kasl S. Psychosocial and clinical correlates of ADHD in a community sample of school-age children. J Am Acad Child Adolesc Psychiatry 1999;38:976-984.

11. Milberger S, Faraone SV, Biederman J, Chu MP, Wilens T. Familial risk analysis of the association between attention-deficit/hyperactivity disorder and psychoactive substance use disorders. Arch Pediatr Adolesc Med 1998;152:945-951. 


\section{Acosta et al.}

12. Arcos-Burgos M, Castellanos FX, Lopera F, Pineda D, Palacio JD, Garcia M et al. Attention-deficit/hyperactivity disorder (ADHD). Feasibility of linkage analysis in a genetic isolate using extended and multigenerational pedigrees. Clin Genet 2002;61: 335-343.

13. Lopera F, Palacio LG, Jimenez I, Villegas P, Puerta IC, Pineda D et al. Genetic and environmental factors discrimination in attention deficit hyperactivity disorder. Rev Neurol 1999;28:660-664.

14. Maher BS, Marazita ML, Moss HB, Vanyukov MM. Segregation analysis of attention deficit hyperactivity disorder. Am J Med Genet 1999;88:71-78.

15. Faraone SV, Biederman J, Chen WJ, Krifcher B, Keenan K, Moore C et al. Segregation analysis of attention deficit hyperactivity disorder. Psychiatr Genet 1992;2:257275.

16. Castellanos FX, Giedd JN, Berquin PC, Walter JM, Sharp W, Tran T et al. Quantitative brain magnetic resonance imaging in girls with attention-deficit/hyperactivity disorder. Arch Gen Psychiatry 2001;58:289-295.

17. Solanto MV, Arnsten AFT, Castellanos FX. The neuroscience of stimulant drug action in ADHD. In: Solanto MV, Arnsten AFT, Castellanos FX, editors. Stimulant drugs and ADHD: Basic and clinical neuroscience. New York: Oxford University Press, 2001;355-379.

18. Castellanos FX, Lee PP, Sharp W, Jeffries NO, Greenstein DK, Clasen LS et al. Developmental trajectories of brain volume abnormalities in children and adolescents with attention-deficit/hyperactivity disorder. JAMA 2002;288:1740-1748.

19. Wortis J. Struwwelpeter Heinrich Hoffmann (1809-1894). Biol Psychiatry 1988;24: 615-618.

20. Rowland AS, Lesesne CA, Abramowitz AJ. The epidemiology of attention-deficit/ hyperactivity disorder (ADHD): a public health view. Ment Retard Dev Disabil Res Rev 2002;8:162-170.

21. American Psychiatric Association. Diagnostic, and Statistical Manual of Mental Disorders, Third Edition, Revised (DSM III-R). American Psychiatric Association, Washington DC, 1987.

22. American Psychiatric Association. Diagnostic, and Statistical Manual of Mental Disorders. Fourth Edition (DSM IV) American Psychiatric Association, Washington DC, 1994.

23. Shaffer D, Fisher P, Dulcan MK, Davies M, Piacentini J, Schwab-Stone ME et al. The NIMH Diagnostic Interview Schedule for Children Version 2.3 (DISC-2.3): description, acceptability, prevalence rates, and performance in the MECA Study: Methods for the Epidemiology of Child and Adolescent Mental Disorders Study. J Am Acad Child Adolesc Psychiatry 1996;35:865-877.

24. Goldman LS, Genel M, Bezman RJ, Slanetz PJ. Diagnosis and treatment of attentiondeficit/hyperactivity disorder in children and adolescents: Council on Scientific Affairs, American Medical Association. JAMA 1998;279:1100-1107.

25. Cantwell DP. Attention deficit disorder: a review of the past 10 years. J Am Acad Child Adolesc Psychiatry 1996;35:978-987.

26. Cantwell DP. Classification of child and adolescent psychopathology. J Child Psychol Psychiatry 1996;37:3-12.

27. Hinshaw SP. On the distinction between attentional deficits/hyperactivity and conduct problems/aggression in child psychopathology. Psychol Bull 1987; 101:443-463.

28. Barkley RA, Cook EH, Diamond A, Zametkin A, Thapar A, Teeter A et al. International consensus statement on ADHD, January 2002. Clin Child Fam Psychol Rev 2002;5:89-111.

29. Murphy R, Barkley A, Bush. Young adults with attention deficit hyperactivity disorder: Subtype differences in comorbidity, educational, and clinical history. J Nerv Ment Dis 2002;190:147-157.

30. Swanson JM, Castellanos FX. Diagnosis, and Treatment of Attention Deficit Hyperactivity Disorder (ADHD). Biological bases of ADHD: neuroanatomy, genetics, and pathophysiology. NIH Consens Statement 1998;16:1-37.

31. Willcutt EG, Pennington BF, Smith SD, Cardon LR, Gayan J, Knopik VS et al. Quantitative trait locus for reading disability on chromosome $6 \mathrm{p}$ is pleiotropic for attention-deficit/hyperactivity disorder. Am J Med Genet 2002;114:260-268.

32. Gillis JJ, Gilger JW, Pennington BF, DeFries JC. Attention deficit disorder in reading-disabled twins: evidence for a genetic etiology. J Abnorm Child Psychol 1992;20: 303-314.

33. Levy F, Hay DA, McStephen M, Wood C, Waldman I. Attention-deficit hyperactivity disorder: a category or a continuum? Genetic analysis of a large-scale twin study. J Am Acad Child Adolesc Psychiatry 1997;36:737-744.

34. Stevenson J. Evidence for a genetic etiology in hyperactivity in children. Behav Gene 1992;22:337-344.

35. Curran S, Rijsdijk F, Martin N, Marusic K, Asherson P, Taylor E et al. CHIP. Defining a dimension of the vulnerability to attention deficit hyperactivity disorder (ADHD) using sibling and individual data of children in a community-based sample. A J Med Genet 2003;119B:86-97.
36. Rasmussen ER, Neuman RJ, Heath AC, Levy F, Hay DA, Todd RD. Replication of the latent class structure of Attention-Deficit Hyperactivity Disorder (ADHD) subtypes in a sample of Australian twins. J Child Psychol Psychiatry 2002;43:1018-1028.

37. Rasmussen ER, Todd RD, Neuman RJ, Heath AC, Reich W, Rohde LA. Comparison of male adolescent-report of attention-deficit/hyperactivity disorder (ADHD) symptoms across two cultures using latent class and principal components analysis. J Child Psychol Psychiatry 2002;43:797-805.

38. Biederman J, Faraone S, Milberger S, Curtis S, Chen L, Marrs A et al. Predictors of persistence and remission of ADHD into adolescence: results from a four-year prospective follow-up study. J Am Acad Child Adolesc Psychiatry 1996;35:343-351.

39. Hill JC, Schoener EP. Age-dependent decline of attention deficit hyperactivity disorder. Am J Psychiatry 1996;153:1143-1146.

40. Harada Y, Satoh Y, Sakuma A, Imai J, Tamaru T, Takahashi T et al. Behavioral and developmental disorders among conduct disorder. Psychiatry Clin Neurosci 2002;56: 621-625.

41. Harada Y, Yamazaki T, Saitoh K. Psychosocial problems in attention-deficit hyperactivity disorder with oppositional defiant disorder. Psychiatry Clin Neurosci 2002, 56:365-369.

42. Geller B, Zimerman B, Williams M, DelBello MP, Frazier J, Beringer L. Phenomenology of prepubertal and early adolescent bipolar disorder: examples of elated mood, grandiose behaviors, decreased need for sleep, racing thoughts and hypersexuality. J Child Adolesc Psychopharmacol 2002;12:3-9.

43. Faraone SV, Biederman J, Monuteaux MC. Attention deficit hyperactivity disorder with bipolar disorder in girls: further evidence for a familial subtype? J Affect Disord 2001;64:19-26.

44. Chang KKD, Steiner H, Ketter TA. Psychiatric phenomenology of child and adolescent bipolar offspring. J Am Acad Child Adolesc Psychiatry 2000;39:453-460.

45. Giedd JN. Bipolar disorder and attention-deficit/hyperactivity disorder in children and adolescents. J Clin Psychiatry 2000;61:1-34.

46. Pliszka SR. Patterns of psychiatric comorbidity with attention-deficit/hyperactivity disorder. Child Adolesc Psychiatr Clin N Am 2000;9:525-540, vii.

47. Roberts N, Parker KCH, Woogh C, Cripps L, Froese AP. Bipolar disorder in ADHD children grown up. J Am Acad Child Adolesc Psychiatry 2000;39:678-679.

48. Sachs GS, Baldassano CF, Truman CJ, Guille C. Comorbidity of attention defici hyperactivity disorder with early- and late-onset bipolar disorder. Am J Psychiatry 2000;157:466-468.

49. Stein MA, Roizen NM, Leventhal BL. Bipolar disorder and ADHD. J Am Acad Child Adolesc Psychiatry 1999;38:1208-1209.

50. Kurlan R, Como PG, Miller B, Palumbo D, Deeley C, Andresen EM et al. The behavioral spectrum of tic disorders: A community-based study. Neurology 2002;59: $414-420$.

51. Comings DE. Clinical and molecular genetics of ADHD and Tourette syndrome. Two related polygenic disorders. Ann N Y Acad Sci 2001;931:50-83.

52. Como PG. Neuropsychological function in Tourette syndrome. Adv Neuro 2001;85: $103-111$.

53. Peterson BS, Pine DS, Cohen P, Brook JS. Prospective, longitudinal study of tic, obsessive-compulsive, and attention-deficit/hyperactivity disorders in an epidemiological sample. J Am Acad Child Adolesc Psychiatry 2001;40:685-695.

54. Spencer T, Biederman J, Coffey B, Geller D, Faraone S, Wilens T. Tourette disorder and ADHD. Adv Neurol 2001;85:57-77.

55. Friedman MC, Chhabildas N, Budhiraja N, Willcutt EG, Pennington BF. Etiology of the comorbidity between RD and ADHD: Exploration of the non-random mating hypothesis. Am J Med Genet 2003;120B:109-115.

56. Faraone SV, Biederman J, Friedman D. Validity of DSM-IV subtypes of attentiondeficit/hyperactivity disorder: a family study perspective. J Am Acad Child Adolesc Psychiatry 2000;39:300-307.

57. Willcutt EG, Pennington BF. Comorbidity of reading disability and attention-deficit/hyperactivity disorder: Differences by gender and subtype. J Learn Disabil 2000; 33:179-191.

58. Willcutt EG, Hartung CM, Lahey BB, Loney J, Pelham WE. Utility of behavior ratings by examiners during assessments of preschool children with attention-deficit/hyperactivity disorder. J Abnorm Child Psychol 1999;27:463-472.

59. Dalsgaard S, Mortensen PB, Frydenberg M, Thomsen PH. Conduct problems, gender and adult psychiatric outcome of children with attention-deficit hyperactivity disorder. Br J Psychiatry 2002;181:416-421.

60. Taylor E, Chadwick O, Heptinstall E, Danckaerts M. Hyperactivity and conduct problems as risk factors for adolescent development. J Am Acad Child Adolesc Psychiatry 1996;35:1213-1226.

61. Biederman J, Wilens T, Mick E, Faraone SV, Weber W, Curtis S et al. Is ADHD a risk factor for psychoactive substance use disorders? Findings from a four-year prospective follow-up study. J Am Acad Child Adolesc Psychiatry 1997;36:21-29.

62. Faraone SV, Biederman J, Monuteaux MC. Toward guidelines for pedigree selection in genetic studies of attention deficit hyperactivity disorder. Genet Epidemiol 2000; $18: 1-16$. 
63. Simkin DR. Adolescent substance use disorders and comorbidity. Pediatr Clin North Am 2002;49:463-477.

64. Wilson JJ, Levin FR. Attention deficit hyperactivity disorder (ADHD) and substance use disorders. Curr Psychiatry Rep 2001;3:497-506.

65. Schubiner H, Tzelepis A, Milberger S, Lockhart N, Kruger M, Kelley BJ et al. Prevalence of attention-deficit/hyperactivity disorder and conduct disorder among substance abusers. J Clin Psychiatry 2000;61:244-251.

66. Mannuzza S, Klein RG, Bessler A, Malloy P, LaPadula M. Adult outcome of hyperactive boys: Educational achievement, occupational rank, and psychiatric status. Arch Gen Psychiatry 1993;50:565-576.

67. Faraone SV, Biederman J, Mennin D, Russell R, Tsuang MT. Familial subtypes of attention deficit hyperactivity disorder: A 4-year follow-up study of children from antisocial-ADHD families. J Child Psychol Psychiatry 1998;39:1045-1053.

68. Smalley SL, McCracken J, McGough J. Refining the ADHD phenotype using affected sibling pair families. Am J Med Genet 2001;105:31-33.

69. Lahey BB, Schaughency EA, Hynd GW, Calrson CL, Nieves N. Attention deficit disorder with and without hyperactivity: Comparison of behavioral characteristics of clinic-referred children. J Am Acad Child Adolesc Psychiatry 1987;26:718-723.

70. Biederman J. Attention-deficit/hyperactivity disorder: A life-span perspective. J Clin Psychiatry 1998;59:4-16.

71. Gaub M, Carlson CL. Gender differences in ADHD: A meta-analysis and critical review. J Am Acad Child Adolesc Psychiatry 1997 36;1036-1045:

72. Rowland AS, Umbach DM, Catoe KE, Stallone L, Long S, Rabiner D, Naftel AJ, Panke D, Faulk R, Sandler DP. Studying the epidemiology of attention-deficit hyperactivity disorder: Screening method and pilot results. Can J Psychiatry 2001; 46:931-940

73. Morrison JR, Stewart MA. A family study of the hyperactive child syndrome. Biol Psychiatry 1971;3:189-195.

74. Risch N, Merikangas K. The future of genetic studies of complex human diseases. Science 1996;273:1516-1517.

75. Risch N, Merikangas K. Genetic analysis of complex diseases. Science 1997;275: 1329-1330.

76. Risch N. Linkage strategies for genetically complex traits, II: The power of affected relative pairs. Am J Hum Genet 1990;46:229-241.

77. Faraone SV. Report from the third international meeting of the Attention-Deficit Hyperactivity Disorder Molecular Genetics Network. Am J Med Genet 2002;114: 272-276.

78. Fisher SE, Francks C, McCracken JT, McGough JJ, Marlow AJ, MacPhie IL et al. A genomewide scan for loci involved in attention-deficit/hyperactivity disorder. Am J Hum Genet 2002;70:1183-1196.

79. Ogdie MN, MacPhie IL, Minassian SL, Yang M, Fisher SE, Francks C et al. A genomewide scan for attention-deficit/hyperactivity disorder in an extended sample: suggestive linkage on 17p11. Am J Hum Genet 2003;72:1268-1279.

80. Bakker SC, van der Meulen EM, Buitelaar JK, Sandkuijl LA, Pauls DL et al. A whole-genome scan in 164 Dutch sib pairs with attention-deficit/hyperactivity disorder: suggestive evidence for linkage on chromosomes 7p and 15q. Am J Hum Genet 2003;72:1251-1260.

81. Arcos-Burgos M, Muenke M. Genetics of population isolates. Clin Genet 2002;61: 233-247.

82. Bravo ML, Montoya JE, Arcos-Burgos M. Polymorphisms of classical markers, genetic structure and phenetic relationships of a black community inhabiting Choco State in Colombia. Homo 2000;51:132-140.

83. Carvajal-Carmonan LG, Ophoff R, Service S, Hartiala J, Molina J, Leon P et al. Genetic demography of Antioquia (Colombia) and the Central Valley of Costa Rica. Hum Genet 2003;112:534-541.

84. Arcos-Burgos M, Castellanos FX, Lopera F, Pineda D, Palacio JD, Rapoport JL et al. Genome-wide scan in multigenerational and extended pedigrees segregating ADHD from a genetic isolate. Am J Hum Genet 2003;73:476

85. Faraone SV, Doyle AE, Mick E, Biederman J. Meta-analysis of the association between the 7-repeat allele of the dopamine D4 receptor gene and attention deficit hyperactivity disorder. Am J Psychiatry 2001;158:1052-1057.

86. Maher BS, Marazita ML, Ferrell RE, Vanyukov MM. Dopamine system genes and attention deficit hyperactivity disorder: a meta-analysis. Psychiatr Genet 2002;12: 207-215.

87. Hawi Z, Lowe N, Kirley A, Gruenhage F, Nothen M, Greenwood T et al. Linkage disequilibrium mapping at DAT1, DRD5 and DBH narrows the search for ADHD susceptibility alleles at these loci. Mol Psychiatry 2003;8:299-308.

88. Curran S, Mill J, Tahir E, Kent L, Richards S, Gould A et al. Association study of a dopamine transporter polymorphism and attention deficit hyperactivity disorder in UK and Turkish samples. Mol Psychiatry 2001;6:425-428.

89. Waldman ID, Rowe DC, Abramowitz A, Kozel ST, Mohr JH, Sherman SL et al. Association and linkage of the dopamine transporter gene and attention-deficit hyperactivity disorder in children: heterogeneity owing to diagnostic subtype and severity. Am J Hum Gene 1998;63:1767-1776.
90. Galili-Weisstub E, Segman RH. Attention Deficit and Hyperactivity Disorder: Review of genetic association studies. Isr J Psychiatry Relat Sci 2003;40:57-66.

91. Arcos-Burgos M, Castellanos FX, Konecki D, Lopera F, Pineda D, Palacio JD et al. Pedigree disequilibrium test (PDT) replicates association and linkage between DRD4 and ADHD in multigenerational and extended pedigrees from a genetic isolate. Mol Psychiatry In press.

92. Mill J, Fisher N, Curran S, Richards S, Taylor E, Asherson P. Polymorphisms in the dopamine D4 receptor gene and attention-deficit hyperactivity disorder. Neuroreport 2003;14:1463-1466.

93. Seaman MI, Fisher JB, Chang F, Kidd KK. Tandem duplication polymorphism upstream of the dopamine D4 receptor gene (DRD4). Am J Med Genet 1999;88: 705-709.

94. McCracken JT, Smalley SL, McGough JJ, Crawford L, Del'Homme M, Cantor RM et al. Evidence for linkage of a tandem duplication polymorphism upstream of the dopamine D4 receptor gene (DRD4) with attention deficit hyperactivity disorder (ADHD). Mol Psychiatry 2000;5:531-536.

95. LaHoste GJ, Swanson M, Wigal SB, Glabe C, King N, Kennedy JL et al. Dopamine $\mathrm{D} 4$ receptor gene polymorphism is associated with attention deficit hyperactivity disorder. Mol Psychiatry 1996;1:121-124.

96. Smith KM, Daly M, Fischer M, Yiannoutsos CT, Bauer L, Barkley R et al. Association of the dopamine beta hydroxylase gene with attention deficit hyperactivity disorder: Genetic analysis of the Milwaukee longitudinal study. Am J Med Genet 2003;119B:77-85.

97. Roman T, Schmitz M, Polanczyk GV, Eizirik M, Rohde LA, Hutz MH. Further evidence for the association between attention-deficit/hyperactivity disorder and the dopamine- $\beta$-hydroxylase gene. Am J Med Genet 2002;114:154-158.

98. Wiggm K, Zai G, Schachar R, Tannock R, Roberts W, Malone M et al. Attention deficit hyperactivity disorder and the gene for dopamine beta-hydroxylase. Am J Psychiatry 2002;159:1046-1048.

99. Bowden CL, Deutsch CK, Swanson JM. Plasma dopamine-beta-hydroxylase and platelet monoamine oxidase in attention deficit disorder and conduct disorder. J Am Acad Child Adolesc Psychiatry 1988;27:171-174.

100. Manor I, Tyano S, Mel E, Eisenberg J, Bachner-Melman R, Kotler M et al. Familybased and association studies of monoamine oxidase A and attention deficit hyperactivity disorder (ADHD): Preferential transmission of the long promoter-region repeat and its association with impaired performance on a continuous performance test (TOVA). Mol Psychiatry 2002;7:626-632.

101. Jiang S, Xin R, Lin S, Qian Y, Tang G, Wang D et al. Linkage studies between attention-deficit hyperactivity disorder and the monoamine oxidase genes. Am J Med Genet 2001;105:783-788.

102. Kirley A, Hawi Z, Daly G, McCarron M, Mullins C, Millar N et al. Dopaminergic system genes in ADHD: Toward a biological hypothesis. Neuropsychopharmacology 2002;27:607-619.

103. Tahir E, Curran S, Yazgan Y, Ozbay F, Cirakoglu B, Asherson PJ. No association between low- and high-activity catecholamine-methyl-transferase (COMT) and attention deficit hyperactivity disorder (ADHD) in a sample of Turkish children. Am J Med Genet 2000;96:285-288.

104. Barr CL, Wigg K, Malone M, Schachar R, Tannock R, Roberts W et al. Linkage study of catechol-O-methyltransferase and attention-deficit hyperactivity disorder. Am J Med Genet 1999;88:710-713.

105. Eisenberg J, Mei-Tal G, Steinberg, A, Tartakovsky E, Zohar A, Gritsenko I et al. Haplotype relative risk study of catechol-O-methyltransferase (COMT) and attention deficit hyperactivity disorder (ADHD): Association of the high-enzyme activity val allele with ADHD impulsive-hyperactive phenotype. Am J Med Genet 1999; 88:497-502.

106. Kustanovich V, Merriman B, McGough J, McCracken JT, Smalley SL, Nelson SF. Biased paternal transmission of SNAP-25 risk alleles in attention-deficit hyperactivity disorder. Mol Psychiatry 2003;8:309-315

107. Brophy K, Hawi Z, Kirley A, Fitzgerald M, Gill M. Synaptosomal-associated protein 25 (SNAP-25) and attention deficit hyperactivity disorder (ADHD): Evidence of linkage and association in the Irish population. Mol Psychiatry 2002;7:913-917.

108. Raber J, Mehta PP, Kreifeldt M, Parsons LH, Weiss F, Bloom FE et al. Coloboma hyperactive mutant mice exhibit regional and transmitter-specific deficits in neurotransmission. J Neurochem 1997;68:176-186.

109. Hess EJ, Collins KA, Wilson MC. Mouse model of hyperkinesis implicates SNAP-25 in behavioral regulation. J Neurosci 1996;16:3104-3111.

110. Steffensen SC, Wilson MC, Henriksen SJ. Coloboma contiguous gene deletion encompassing SNAP alters hippocampal plasticity. Synapse 1996;22:281-289.

111. Kent L, Doerry U, Hardy E, Parmar R, Gingell K, Hawi Z et al. Evidence that variation at the serotonin transporter gene influences susceptibility to attention deficit hyperactivity disorder (ADHD): analysis and pooled analysis. Mol Psychiatry 2002;7:908-912.

112. Retz W, Thome J, Blocher D, Baader M, Sler M. Association of attention deficit hyperactivity disorder-related psychopathology and personality traits with the se- 
rotonin transporter promoter region polymorphism. Neurosci Lett 2002;319:133136.

113. Cottingham Jr RW, Idury RM, Schaffer AA. Faster sequential genetic linkage computations. Am J Hum Genet 1993;53:252-263.

114. Lathrop GM, Lalouel JM, Julier C, Ott J. Strategies for multilocus analysis in humans. Proc Natl Acad Sci U S A 1984;81:3443-3446.

115. Sobel E, Lange, K. Descent graphs in pedigree analysis: applications to haplotyping, location scores, and marker sharing statistics. Am J Hum Genet 1996;58:1323-1337.

116. Minde K, Eakin L, Hechtman L, Ochs E, Bouffard R, Greenfield B et al. The psychosocial functioning of children and spouses of adults with ADHD.J Child Psychol Psychiatry 2003;44:637-646.

117. Niederhofer H, Hackenberg B, Stier R, Lanzendorfer K, Kemmler G, Lechner T. Features in families of boys with hyperkinetic and emotional disorders. Psychol Rep 2003;92:849-852.

118. Pliszka R. Effect of anxiety on cognition, behavior, and stimulant response in ADHD. J Am Acad Child Adolesc Psychiatry 1989;28:882-887.

119. Jensen PS, Arnold LE, Richters JE, Severe JB, Vereen D, Vitiello B et al. A 14-month randomized clinical trial of treatment strategies for attention-deficit/hyperactivity disorder. Arch Gen Psychiatry 1999;56:1073-1086.

120. Pauls DL, Bailey JN, Carter AS, Allen CR, Egeland JA. Complex segregation analyses of old order Amish families ascertained through bipolar I individuals. Am J Med Genet 1995;60:290-297.

121. Blangero J, Elston RC. Familial analysis of bipolar affective disorder using logistic models. Genet Epidemiol 1989;6:221-227.

122. Sham PC, Morton NE, Muir WJ, Walker M, Collins A, Shields DC et al. Segregation analysis of complex phenotypes: an application to schizophrenia and auditory P300 latency. Psychiatr Gene 1994;4:29-38.

123. Risch N, Baron M. Segregation analysis of schizophrenia and related disorders. Am J Hum Genet 1984;36:1039-1059.

124. Ruiz A, Blanco R, Arcos M, Santander J, San Martin A. Complex segregation analysis of schizophrenia in Santiago, Chile. Schizophr Res 1997;26:65-69.

125. Cavallini MC, Pasquale L, Bellodi L, Smeraldi E. Complex segregation analysis for obsessive compulsive disorder and related disorders. Am J Med Genet 1999;88:3843.

126. Pauls DL, Pakstis AJ, Kurlan R, Kidd KK, Leckman JF, Cohen DJ et al. Segregation and linkage analyses of Tourette's syndrome and related disorders. J Am Acad Child Adolesc Psychiatry 1990;29:195-203.

127. Walkup JT, LaBuda MC, Singer HS, Brown J, Riddle MA, Hurko O. Family study and segregation analysis of Tourette syndrome: Evidence for a mixed model of inheritance. Am J Hum Genet 1996;59:684-693.

128. Berquin PC, Giedd N, Jacobsen LK, Hamburger SD, Krain AL, Rapoport JL et al. The cerebellum in attention-deficit/hyperactivity disorder: a morphometric study. Neurology 1998;50:1087-1093.

129. Giedd JN, Castellanos FX, Casey BJ, Kozuch P, King AC, Hamburger SD et al. Quantitative morphology of the corpus callosum in attention deficit hyperactivity disorder. Am J Psychiatry 1994;151:665-669.

130. Castellanos FX, Giedd JN, Eckburg P, Marsh WL, Vaituzis AC, Kaysen D et al. Quantitative morphology of the caudate nucleus in attention deficit hyperactivity disorder. Am J Psychiatry 1994;151:1791-1796.

131. Castellanos FX, Giedd JN, Marsh WL, Hamburger SD, Vaituzis AC, Dickstein DP et al. Quantitative brain magnetic resonance imaging in attention-deficit/hyperactivity disorder. Arch Gen Psychiatry 1996;53:607-616.

132. Castellanos FX, Sharp WS, Gottesman RF, Greenstein DK, Giedd JN, Rapoport JL. Anatomic brain abnormalities in monozygotic twins discordant for attention-deficit/hyperactivity disorder. Am J Psychiatry 2003;160:1693-1696.

133. Mostofsky SH, Cooper KL, Kates WR, Denckla MB, Kaufmann WE. Smaller prefrontal and premotor volumes in boys with attention-deficit/hyperactivity disorder. Biol Psychiatry 2002;52:785-794.

134. Hesslinger B, Tebartz VE, Thiel T, Haegele K, Hennig J, Ebert D. Frontoorbital volume reductions in adult patients with attention deficit hyperactivity disorder. Neurosci Lett 2002;328:319-321.

135. Hynd GW, Hern KL, Novey ES, Eliopulos D, Marshall R, Gonzalez J et al. Attention deficit-hyperactivity disorder and asymmetry of the caudate nucleus. J Child Neurol 1993;8:339-347.

136. Hynd GW, Semrud-Clikeman M, Lorys AR, Novey ES, Eliopulos D, Lyytinen H. Corpus callosum morphology in attention deficit-hyperactivity disorder: morphometric analysis of MRI. J Learn Disabil 1991;24:141-146.

137. Durston S, Tottenham NT, Thomas KM, Davidson MC, Eigsti IM, Yang Y et al. Differential patterns of striatal activation in young children with and without ADHD. Biol Psychiatry 2003;53:871-878.

138. Vaidya CJ, Austin G, Kirkorian G, Ridlehuber, HW, Desmond JE, Glover GH et al. Selective effects of methylphenidate in attention deficit hyperactivity disorder: A functional magnetic resonance study. Proc Natl Acad Sci US A 1998;95:1449414499.
139. El Sayed E, Larsson JO, Persson HE, Rydelius PA. Altered cortical activity in children with attention-deficit/hyperactivity disorder during attentional load task. J Am Acad Child Adolesc Psychiatry 2002;41:811-819.

140. Kim BN, Lee JS, Shin MS, Cho SC, Lee DS. Regional cerebral perfusion abnormalities in attention deficit/hyperactivity disorder: Statistical parametric mapping analysis. Eur Arch Psychiatry Clin Neurosci 2002;252:219-225.

141. Koth CW, Cutting LE, Denckla MB. The association of neurofibromatosis type 1 and attention deficit hyperactivity disorder. Neuropsychol Dev Cogn Sect C Child Neuropsychol 2000;6:185-194.

142. Heussler HS, Suri M, Young ID, Muenke M. Extreme variability of expression of a Sonic Hedgehog mutation: Attention difficulties and holoprosencephaly. Arch Dis Child 2002;86:293-296.

143. McCauley E, Kay T, Ito J, Treder R. The Turner syndrome: Cognitive deficits, affective discrimination, and behavior problems. Child Dev 1987;58:464-473.

144. McCauley E, Sybert VP, Ehrhardt AA. Psychosocial adjustment of adult women with Turner syndrome. Clin Genet 1986;29:284-290.

145. McCauley E, Ito J, Kay T. Psychosocial functioning in girls with Turner's syndrome and short stature: social skills, behavior problems, and self-concept. J Am Acad Child Psychiatry 1986;25:105-112.

146. Hoogenraad CC, Koekkoek B, Akhmanova A, Krugers H, Dortland B, Miedema M et al. Targeted mutation of Cyln2 in the Williams syndrome critical region links CLIP-115 haploinsufficiency to neurodevelopmental abnormalities in mice. Nat Genet 2002;32L:116-127.

147. Bawden HN, MacDonald GW, Shea S. Treatment of children with Williams syndrome with methylphenidate. J Child Neurol 1997;12:248-252.

148. Backes M, Genc B, Schreck J, Doerfler W, Lehmkuhl G, von Gontard A. Cognitive and behavioral profile of fragile X boys: Correlations to molecular data. Am J Med Genet 2000;95:150-156.

149. Blair IP, Gibson RR, Bennett CL, Chance PF. Search for genes involved in Joubert syndrome: evidence that one or more major loci are yet to be identified and exclusion of candidate genes EN1, EN2, FGF8, and BARHL1. Am J Med Genet 2002;107: 190-196.

150. Greenberg F, Lewis RA, Potocki L, Glaze D, Parke J, Killian J et al. Multi-disciplinary clinical study of Smith-Magenis syndrome (deletion 17p11.2). Am J Med Genet 1996;62:247-254.

151. Greenberg F, Guzzetta V, Montes DOL, Magenis RE, Smith AC, Richter SF et al. Molecular analysis of the Smith-Magenis syndrome: a possible contiguous-gene syndrome associated with del(17)(p11.2). Am J Hum Genet 1991;49:1207-1218.

152. Smith AC, Dykens E, Greenberg F. Sleep disturbance in Smith-Magenis syndrome (del 17 p11.2). Am J Med Genet 1998;81:186-191.

153. Smith AC, Dykens E, Greenberg F. Behavioral phenotype of Smith-Magenis syndrome (del 17p11.2). Am J Med Genet 1998;81:179-185.

154. Huijbregts SC, de Sonneville LM, Licht R, van Spronsen FJ, Sergeant JA. Shortterm dietary interventions in children and adolescents with treated phenylketonuria: effects on neuropsychological outcome of a well-controlled population. J Inherit Metab Dis 2002;25:419-430.

155. Huijbregts SC, de Sonneville LM, Licht R, van Spronsen FJ, Verkerk PH, Sergeant JA. Sustained attention and inhibition of cognitive interference in treated phenylketonuria: associations with concurrent and lifetime phenylalanine concentrations. Neuropsychologia 2002;40:7-15.

156. Ullrich K, Weglage J, Oberwittler C, Pietsch M, Funders B, von Eckardstein Colombo JP. Effect of L-dopa on visual evoked potentials and neuropsychological tests in adult phenylketonuria patients. Eur J Pediatr 1996;155(suppl 1):S74-S77.

157. Weglage J, Schmidt E, Funders B, Pietsch M, Ullrich K. Sustained attention in untreated non-PKU-hyperphenylalaninemia. J Clin Exp Neuropsychol 1996;18:343-348.

158. Weglage J, Fundersm B, Ullrich K, Rupp A, Schmidt E. Psychosocial aspects in phenylketonuria. Eur J Pediatr 1996;155(suppl 1):S101-S104.

159. O’Malley KD, Nanson J. Clinical implications of a link between fetal alcohol spectrum disorder and attention-deficit hyperactivity disorder. Can J Psychiatry 2002; 47:349-354.

160. Niklasson L, Rasmussen P, Oskarsdottir S, Gillberg, C. Chromosome 22q11 deletion syndrome (CATCH 22): neuropsychiatric and neuropsychological aspects. Dev Med Child Neurol 2002;44:44-50.

161. Niklasson L, Rasmussen P, Oskarsdottir S, Gillberg C. Neuropsychiatric disorders in the 22q11 deletion syndrome. Genet Med 2001;3:79-84.

162. Graf WD, Unis AS, Yates CM, Sulzbacher S, Dinulos MB, Jack RM et al. Catecholamines in patients with 22q11.2 deletion syndrome and the low-activity COMT polymorphism. Neurology 2001;57:410-416.

163. Bloom DR, Levin, HS, Ewing-Cobbs L, Saunders AE, Song J, Fletcher JM et al. Lifetime and novel psychiatric disorders after pediatric traumatic brain injury. J Am Acad Child Adolesc Psychiatry 2001;40:572-579. 
164. Slomine BS, Gerring JP, Grados MA, Vasa R, Brady KD, Christensen JR et al. Performance on measures of executive function following pediatric traumatic brain injury. Brain Inj 2002;16:759-772.

165. Anderson SW, Damasio H, Tranel D, Damasio AR. Long-term sequelae of prefrontal cortex damage acquired in early childhood. Dev Neuropsychol 2000;18:281-296.

166. DeLong GR. Mid-gestation right basal ganglia lesion: clinical observations in two children. Neurology 2002;59:54-58.

167. Pineda DA, Lopera F, Henao GC, Palacio JD, Castellanos FX. [Confirmation of the high prevalence of attention deficit disorder in a Colombian community]. Rev Neurol 2001;32:217-222.

168. Vasconcelos MM, Werner J Jr, Malheiros AF, Lima DF, Santos IS, Barbosa JB. [Attention deficit/hyperactivity disorder prevalence in an inner city elementary school]. Arq Neuropsiquiatr 2003;61:67-73.

169. Pineda DA, Lopera F, Palacio JD, Ramirez D, Henao GC. Prevalence estimations of attention-deficit/hyperactivity disorder: Differential diagnoses and comorbidities in a Colombian sample. Int J Neurosci 2003;113:49-71.

170. Benjasuwantep B, Ruangdaraganon N, Visudhiphan P. Prevalence and clinica characteristics of attention deficit hyperactivity disorder among primary school students in Bangkok. J Med Assoc Thai 2002;85 Suppl 4:S1232-S1240.

171. Breton J, Bergeron L, Valla JP, Berthiaume C, Gaudet N, Lambert J et al. Quebec child mental health survey: prevalence of DSM-III-R mental health disorders. J Child Psychol Psychiatry 1999;40:375-384.

172. Wolraich ML, Hannah JN, Pinnock TY, Baumgaertel A, Brown J. Comparison of diagnostic criteria for attention-deficit hyperactivity disorder in a county-wide sample. J Am Acad Child Adolesc Psychiatry 1996;35:319-324.

173. Baumgaertel A, Wolraich ML, Dietrich M. Comparison of diagnostic criteria for attention deficit disorders in a German elementary school sample. J Am Acad Child Adolesc Psychiatry 1995;34:629-638.

174. Pelham WE Jr, Gnagy EM, Greenslade KE, Milich R. Teacher ratings of DSM-III-R symptoms for the disruptive behavior disorders. J Am Acad Child Adolesc Psychiatry 1992;31:210-218.

175. Smalley SL, Bailey JN, Palmer CG, Cantwell DP, McGough JJ, Del'Homme MA et al. Evidence that the dopamine D4 receptor is a susceptibility gene in attention deficit hyperactivity disorder. Mol Psychiatry 1998;3:427-430.

176. Castellanos FX, Lau E, Tayebi N, Lee P, Long RE, Giedd JN et al. Lack of association between a dopamine- 4 receptor polymorphism and attention-deficit/hyperactivity disorder: genetic and brain morphometric analyses. Mol Psychiatry 1998;3:431-434.

177. Swanson JM, Sunohara GA, Kennedy JL, Regino R, Fineberg E, Wigal T et al. Association of the dopamine receptor D4 (DRD4) gene with a refined phenotype of attention deficit hyperactivity disorder (ADHD): a family-based approach. Mol Psychiatry 1998;3:38-41.

178. Rowe DC, Stever C, Giedinghagen LN, Gard JM, Cleveland HH, Terris ST et al. Dopamine DRD4 receptor polymorphism and attention deficit hyperactivity disorder. Mol Psychiatry 1998;3:419-426.

179. Comings DE, Gonzalez N, Wu SJ, Gade R, Muhleman D, Saucier G et al. Studies of the 48 bp repeat polymorphism of the DRD4 gene in impulsive, compulsive, addictive behaviors: Tourette syndrome, ADHD, pathological gambling, and substance abuse. Am J Med Genet 1999;88:358-368.

180. Faraone SV, Biederman J, Weiffenbach B, Keith T, Chu MP, Weaver A et al. Dopamine D4 gene 7-repeat allele and attention deficit hyperactivity disorder. Am J Psychiatry 1999;156:768-770.
181. Eisenberg J, Zohar A, Mei-Tal G, Steinberg A, Tartakovsky E, Gritsenko I et al. A haplotype relative risk study of the dopamine D4 receptor (DRD4) Exon III repeat polymorphism and attention deficit hyperactivity disorder (ADHD). Am J Med Genet 2000;96:258-261

182. Hawi Z, McCarron M, Kirley A, Daly G, Fitzgerald M, Gill M. No association of the dopamine DRD4 receptor (DRD4) gene polymorphism with attention deficit hyperactivity disorder (ADHD) in the Irish population. Am J Med Genet 2000;96: $268-272$.

183. Holmes J, Payton A, Barrett JH, Hever T, Fitzpatrick H, Trumper AL et al. A family-based and case-control association study of the dopamine D4 receptor gene and dopamine transporter gene in attention deficit hyperactivity disorder. $\mathrm{Mol}$ Psychiatry 2000;5:523-530.

184. Kotler M, Manor I, Sever Y, Eisenberg J, Cohen H, Ebstein RP et al. Failure to replicate an excess of the long dopamine D4 exon III repeat polymorphism in ADHD in a family-based study. Am J Med Genet 2000;96:278-281.

185. Muglia P, Jain U, Macciardi F, Kennedy JL. Adult attention deficit hyperactivity disorder and the dopamine D4 receptor gene. Am J Med Genet 2000;96:273277.

186. Muglia P, Jain U, Basile VS, Kennedy JL. Adult ADHD: Association with the dopamine D4 receptor gene. Am J Hum Genet 1999;65:A462.

187. Tahir E, Yazgan Y, Cirakoglu B, Ozbay F, Waldman I, Asherson PJ. Association and linkage of DRD4 and DRD5 with attention deficit hyperactivity disorder (ADHD) in a sample of Turkish children. Mol Psychiatry 2000;5:396-404.

188. Sunohara GA, Roberts W, Malone M, Schachar RJ, Tannock R, Basile VS et al. Linkage of the dopamine $\mathrm{D} 4$ receptor gene and attention-deficit/hyperactivity disorder. J Am Acad Child Adolesc Psychiatry 2000;39:1537-1542.

189. Hawi Z, Millar N, Daly G, Fitzgerald M, Gill M. No association between catechol-O-methyltransferase (COMT) gene polymorphism and attention deficit hyperactivity disorder (ADHD) in an Irish sample. Am J Med Gene 2000;96: 282-284.

190. Manor I, Kotler M, Sever Y, Eisenberg J, Cohen H, Ebstein RP et al. Failure to replicate an association between the catechol-O-methyltransferase polymorphism and attention deficit hyperactivity disorder in a second, independently recruited Israeli cohort. Am J Med Genet 2000;96:858-860.

191. Quist JF, Barr CL, Schachar R, Roberts W, Malone M, Tannock R et al. Evidence for the serotonin HTR2A receptor gene as a susceptibility factor in attention deficit hyperactivity disorder (ADHD). Mol Psychiatry 2000;5:537-54.

192. Cook EH Jr, Stein MA, Krasowski MD, Cox NJ, Olkon DM, Kieffer, JE et al Association of attention deficit disorder and the dopamine transporter gene. Am J Hum Genet 1995;56:993-998.

193. Gill M, Daly G, Heron S, Hawi Z, Fitzgerald M. Confirmation of association between attention deficit hyperactivity disorder and a dopamine transporter polymorphism. Mol Psychiatry 1997;2:311-313.

194. Barr CL, Xu C, Kroft J, Feng Y, Wigg K, Zai G et al. Haplotype study of three polymorphisms at the dopamine transporter locus confirm linkage to attentiondeficit/hyperactivity disorder. Biol Psychiatry 2001;49:333-339.

195. Mill J, Curran S, Kent L, Gould A, Huckett L, Richards S et al. Association study of a SNAP-25 microsatellite and attention deficit hyperactivity disorder. Am J Med Genet 2002;114:269-271. 